\title{
Physicochemical and protein characterization of lima bean (Phaseolus lunatus L) seed
}

\author{
${ }^{1,4}$ Palupi, H.T., ${ }^{2, *}$ Estiasih, T., ${ }^{2}$ Yunianta and ${ }^{3}$ Sutrisno, A. \\ ${ }^{1}$ Doctoral Program of Food Science, Faculty of Agricultural Technology, Universitas Brawijaya \\ Jalan Veteran, Malang, Indonesia 65145 \\ ${ }^{2}$ Department of Food Technology, Faculty of Agricultural Technology, Universitas Brawijaya \\ Jalan Veteran, Malang, Indonesia 65145 \\ ${ }^{3}$ Department of Biotechnology, Faculty of Agricultural Technology, Universitas Brawijaya \\ Jalan Veteran, Malang, Indonesia 65145 \\ ${ }^{4}$ Department of Food Science and Technology, Faculty of Agriculture, Universitas Yudarta \\ Jalan Yudharta, Purwosari, Pasuruan, Indonesia
}

\begin{abstract}
Article history:
Received: 14 February 2021

Received in revised form: 22 March 2021

Accepted: 17 June 2021

Available Online: 5 February 2022
\end{abstract}

Keywords:

Anti-nutrition,

Electrophoretic pattern,

Oligosaccharide,

Protein profile,

Proximate

DOI:

https://doi.org/10.26656/fr.2017.6(1).107

\begin{abstract}
Lima bean (Phaseolus lunatus L) is native to Latin America and has spread out worldwide, thus having a high level of diversity. The lima bean seed from a specific region might have different characteristics from others. This study was aimed to characterize the physicochemical and protein of the dry seed of lima bean from Indonesia based on its solubility, electrophoretic pattern, and amino acid profile. The result showed that carbohydrate $(68.89 \pm 1.55 \%)$ was the major component, with starch $(41.96 \pm 1.10 \%)$ as the predominant. The amylopectin was higher than amylose. Dietary fibre $(27.87 \pm 0.37 \%)$ was significant and dominated by insoluble one $(25.47 \pm 0.32 \%)$. The fat content $(1.15 \pm 0.04 \%)$ was low and ash $(3.67 \pm 0.47 \%)$ comprised of magnesium, phosphorus, potassium, calcium, and iron with the content of $184,75,38,11$, and $10 \mathrm{mg} / 100 \mathrm{~g}$, respectively. Total phenolic compounds of this seed were $1.29 \pm 0.02 \mathrm{mg} / \mathrm{g}$, phytic acid $11.57 \pm 0.03 \mathrm{mg} / \mathrm{g}$, saponins $16.84 \pm 0.42 \mathrm{mg} / \mathrm{g}$, and trypsin inhibitors $36.07 \pm 0.11 \mathrm{TIU} / \mathrm{g}$. $\mathrm{HCN}$ was found significantly at $30.99 \pm 0.29 \mathrm{ppm}$. Oligosaccharides were $5.93 \pm 0.29 \%$ that comprised of raffinose $1.22 \pm 0.08 \%$ and stachyose $4.61 \pm 0.21 \%$. Protein content was moderate $(15.93 \pm 0.55 \%)$ that comprised of albumin $18.47 \pm 0.62 \%$, globulin $56.20 \pm 2.00 \%$, prolamin $3.14 \pm 0.20 \%$, and glutelin $22.69 \pm 1.60 \%$. The molecular weight of this protein was $10-141 \mathrm{kDa}$ with 12 polypeptides. Globulin had 12 polypeptides of 10 to $124 \mathrm{kDa}$. Albumin had 18 to $116 \mathrm{kDa}$ molecular weights, while glutelin had six polypeptides of 13 to $109 \mathrm{kDa}$. Prolamin did not have visible polypeptides. Lysine, leucine, valine, and phenylalanine were the primary essential amino acids with high lysine but low methionine and cysteine. In conclusion, lima bean seed is a source of carbohydrates and minerals, with a moderate protein content dominated by the globulin. The polypeptide profile of lima bean seed is varied depending on the protein fractions. The occurrence of antinutrition might hinder its utilization as a protein source. HCN as a toxicant should be removed to obtain a safe seed for consumption.
\end{abstract}

\section{Introduction}

Legumes are dicotyledonous seeds of plants belonging to the Leguminosae family (Hoover et al., 2010), which have been consumed for thousands of years as a part of the traditional diet throughout the world. Legumes are considered an essential part of the human diet in many countries worldwide and the second-largest source of human food after cereals. Legumes are an excellent source of complex carbohydrates, protein, dietary fibre, and vitamins and minerals. The high lysine content in legume protein makes legume ideal for blending with other commodities. The nutritious seeds significantly contribute to food security, sustainable agriculture, biodiversity, and environmental change mitigation (Boukid et al., 2019). In recent years, legumes are recommended as health-promoting foods by health 
organizations and dieticians (Hall et al., 2017). The Food and Agriculture Organization of the United Nations formally declared 2016 as the "International Year of Pulses" (IYP) to raise awareness about these important crops essential for sustainable agriculture and their nutrient richness, which improves human health nutrition. It is expected that reviving legumes production by utilizing the local biodiversity will have economic, environmental, and societal impacts since consumer well -being and health are directly affected by the food they eat.

Phaseolus lunatus L., also known as lima bean or butter bean, belongs to the Fabaceae family, a vining tropical legume crop cultivated mostly in temperate and subtropical regions in Africa and Southeast Asia (Sandoval-Peraza, 2020). Lima bean is native to tropical America. The Spaniards introduced lima beans throughout the Americas and the Southeast Asia region (Lim, 2012). It adapted to highly leach infertile soils of the more humid regions (Aremu et al., 2016), with a high level of genetic diversity worldwide (e Lacerda et al., 2017). Therefore, the lima bean seed from a specific region might have different characteristics from other origins. So far, this legume is not extensively consumed (Diniyah et al., 2020) due to the low productivity and hard texture of dry beans. This high protein content is an advantage that might be used to provide nutritious food products and solve nutritional problems due to the lack of protein consumption.

Lima bean seeds are considered to be good sources of nutrients (Jayalaxmi et al., 2016), such as a valuable source of proteins with content from 14.24 to $24.92 \%$ (Ibeabuchi et al., 2019) and rich in essential amino acids (FAO, 2017). They provide complex carbohydrates, mainly starch and dietary fiber, vitamins (B complex), and minerals (zinc, iron, and calcium) (Campos-Vega et al., 2010). The most abundant proteins are storage proteins, primarily globulin and albumin (Agarwal, 2017). In addition to their good macronutrient composition, lima bean is considered beneficial for health because of the low glycemic index due to the presence of slow-release carbohydrates (Bello-Pérez et al., 2007). However, like other legumes, lima bean also contains antinutritional components, including saponin, phytic acid, trypsin inhibitors, phenolic compounds, and contains toxic compounds of cyanogenic glycosides (Bolade et al., 2017; Sandoval-Peraza et al., 2020). Antinutritions decrease the nutritional quality of the legumes. On the other hand, some of these compounds might have health benefits as an antioxidant, anti-cancer, and other health benefits (Campos-Vega et al., 2010).

Bean protein characteristics are very important to explore because legume is a source of essential nutrients. Protein fractions based on solubility will determine their uses in food processing. Meanwhile, the amino acid profile of the protein also affects its bioavailability in the body. Different environments and long adaptation to a specific region might result in different physicochemical and protein characteristics. This study aimed to characterize the physicochemical and protein of lima bean with long adaptation to Indonesia's growing environment.

\section{Materials and methods}

The seeds of lima bean (Phaseolus lunatus L.) were obtained from Malang, East Jawa Province, Indonesia. The seeds were carefully cleaned and freed from foreign materials and sundried for 3 days and then stored in polyethylene bags. All chemicals are pro-analysis grade and the standards for chromatography analysis (oligosaccharides and amino acids) were obtained from Sigma Aldrich (Singapore).

\subsection{Physical characterization}

Seed length, width, and thickness of dry lima bean seed were measured with a vernier caliper. The colour was measured using a Chromameter CR-100 (Minolta) in terms of L (lightness), a (redness and greenness), and $\mathrm{b}$ (yellowness and blueness). The weight and volume of one hundred and ten seeds of lima bean, respectively, were measured using the methods of Wani et al. (2017) with slight modifications.

\subsection{Chemical analysis}

\subsubsection{Proximate and carbohydrate analysis}

Proximate analysis of the dry lima bean was carried out to determine crude protein, ash, crude fat, and moisture content by AOAC (2005) methods. The total carbohydrate was determined by difference. The starch content was measured by the direct acid hydrolysis method (AOAC, 2005). The amylose content was determined by the spectrophotometric method (ISO 6647). Total (TDF), soluble, and insoluble dietary fibres were measured by the enzymatic-gravimetric method of AOAC (991.43). All the analysis was conducted in three replications. All data were calculated as dry basis (db).

\subsubsection{Minerals analysis}

The samples were dry-ashed according to the AOAC method (2005). The aliquot was analysed for potassium, magnesium, calcium, and iron using atomic absorption spectrophotometer (AA-6200 Shimadzu), while phosphorus was analysed colorimetrically by the AOAC method (2005) using Genesis 10S UV-Vis Spectrophotometer. 


\subsubsection{Anti-nutrition and HCN analysis}

The colorimetric (Wade Reagent) method was applied to determine the phytic acid content described by Lai et al. (2013). Total phenolic content (TPC) was determined using Folin-Ciocalteu phenol reagent at an absorbance of $740 \mathrm{~nm}$. TPC was expressed as $\mathrm{mg}$ gallic acid equivalent per gram (mg GAE/g) (Padhi et al., 2017). The saponin content was determined using the spectrophotometric method as described by Lai et al. (2013). Trypsin inhibitor activity (TIA) was measured following the procedure by Kakade et al. (1974). The determination of the cyanide (HCN) content of the samples was by the alkaline titration method of the AOAC (1990) (Bolade et al., 2017).

\subsubsection{Oligosaccharides analysis}

Oligosaccharides were analysed using the method of Wang et al. (2007) with a slight modification. Oligosaccharides were extracted by adding $20 \mathrm{~mL}$ of $70 \%$ ethanol, then heated in a water bath at $70^{\circ} \mathrm{C}$ for one hour. The extract was filtered by a $0.45 \mu \mathrm{m}$ membrane filter and put in a vial. Sodium azide was added with a volume of $10 \%$ of the sample volume. The sample was injected into the HPLC system consisting of a degasser (model G1322A Agilent), a solvent pump (model G1310A Agilent), and a refractive index detector (model G1362A Agilent). HPLC columns for carbohydrates (ZORBAX carbohydrate analysis columns) with dimensions of $150 \mathrm{~mm} \times 4.6 \mathrm{~mm} \times 5 \mu \mathrm{m}$ (Agilent), coated with 3 -aminopropyl silane on the silica particles. The mobile phase was a mixture of acetonitrile: water (80:20) with a $1 \mathrm{~mL} / \mathrm{min}$ flow rate. The standards of oligosaccharides used were raffinose and stachyose.

\subsection{Protein characterization}

\subsubsection{Protein extraction}

The total protein was extracted using a slight modification of Gupta et al. (2014). Dry lima bean seed was ground and sieved at 100 mesh. Lima bean flour $(100 \mathrm{mg})$ was dissolved in $1 \mathrm{~mL}$ of $0.1 \mathrm{M}$ Tris-HCl buffer ( $\mathrm{pH}$ 8.0). The crude homogenate was stirred intermittently for $2 \mathrm{hrs}$ and then centrifuged at $8,000 \times \mathrm{g}$ for 20 mins. The supernatant was protein extract used for protein fraction and electrophoretic pattern analysis using Sodium Dodecyl Sulfate-Polyacrylamide Gel Electrophoresis (SDS PAGE).

\subsubsection{Protein fractionation}

Extracted protein was fractionated based on solubility into albumin (water-soluble), globulin (saltsoluble), prolamin (alcohol-soluble), and glutelin (alkalisoluble). Proteins were separated by the Osborne method (Alghamdi et al., 2019) with a slight modification.
Briefly, $100 \mathrm{mg}$ of lima bean flour was mixed with distilled water $(1 \mathrm{~mL})$, and the mixture was stirred intermittently for $2 \mathrm{hrs}$ and then centrifuged at $8,000 \times \mathrm{g}$ for 20 mins. The supernatant was an albumin fraction. The residue was mixed with $5 \% \mathrm{NaCl}$ and stirred for 2 $\mathrm{hrs}$ before being centrifuged at $8,000 \times g$ for $20 \mathrm{mins}$. The supernatant was a globulin fraction. The residue from the globulin fraction was mixed with $1 \mathrm{~mL}$ of $70 \%$ ethanol and stirred intermittently for $2 \mathrm{hrs}$. The mixture was then centrifuged at $8,000 \times \mathrm{g}$ for $20 \mathrm{mins}$, and the supernatant was a prolamin fraction. The residue from the prolamin fraction was mixed with $1 \mathrm{~mL}$ of $0.1 \mathrm{~N} \mathrm{NaOH}$ and stirred intermittently for $2 \mathrm{hrs}$ before centrifugation at $8,000 \times g$ for 20 mins. The supernatant was a glutelin fraction. All these four fractions were analysed from their electrophoretic protein pattern by SDS-PAGE analysis. Protein concentration of protein extract and protein fractions were determined by the Biuret method using bovine serum albumin (BSA) as a standard (Wati et al., 2009).

\subsubsection{SDS-PAGE analysis}

Protein extract and protein fractions were analysed using SDS-polyacrylamide gel electrophoresis $(12 \%$ separating gel and 4\% stacking gel) by the method of Vasconcelos et al. (2010). Protein extract and its four fractions, each was $50 \mathrm{~mL}$, was mixed separately with the loading buffer $(125 \mathrm{mM}$ M Tris- $\mathrm{HCl}$ buffer $\mathrm{pH} 6.8$, containing $10 \%$ SDS, $50 \%$ glycerol, $1 \%$ bromophenol blue, and $200 \mathrm{mM} \mathrm{b}$-mercaptoethanol) and heated at $100^{\circ} \mathrm{C}$ for $3-5$ mins. After heating, each sample was loaded in the wells of the gel. The electrophoresis was performed at a constant voltage of $125 \mathrm{~V}$ for 30 mins. The protein was stained with Coomassie Brilliant Blue R -250 and de-stained with methanol-acetic acid solution after separation.

\subsubsection{Amino acid analysis}

Amino acid profile determination was analysed using a Waters Acquity Ultra-High-Performance Liquid Chromatography (UHPLC) $\mathrm{H}$ Class and $\mathrm{H}$ Class Bio Amino Acid Analysis System Guide. UHPLC method was used for the identification of 17 amino acids e.g Lserine (Ser), L-glutamic acid (Glu), L-phenylalanine (Phe), L-isoleucine (Iso), L-valine (Val), L-alanine (Ala), L-arginine (Arg), glycine (Gly), L-lysine (Lys), Laspartic acid (Asp), L-leucine (Leu), tyrosine (Tyr), proline (Pro), threonine (Thr), histidine (His), cysteine (Cys) and methionine (Met). The method was equipped with column AccQ. Tag Ultra C18 $1.7 \mu \mathrm{m}(2.1 \times 100$ $\mathrm{mm}$ ), with column temperature at $49^{\circ} \mathrm{C}, 1 \mu \mathrm{l}$ of injection volume, flow rate of $0.5 \mathrm{~m} / \mathrm{min}$, and PDA detector at 260 $\mathrm{nm}$ wavelength. The gradient composition of mobile phase systems was as follows: A: Eluent A Acq. Tag 
Ultra Eluent A 100\%; B: Eluent B Acq.Tag Ultra Eluent B: Aquabidest 90:10; C: Aquabidest; D: Eluent B Acq.Tag Ultra Eluent B 100\%.

\section{Result and discussion}

\subsection{Physical properties}

The information regarding the physical properties such as size, shape, density, and legumes seeds is crucial in designing equipment for harvesting, transporting, cleaning, separating, packaging, storing, and processing of the seeds into different foods (Wani et al., 2017). The physical properties of dry lima bean seeds are presented in Table 1. The length, width, and thickness of the lima bean were slightly higher than those for the same legume reported by Gupta et al. (2018). The weight of this seed was higher than other legumes such as Phaseolus coccineus L. var. purple scarlet runner, Phaseolus vulgaris (Corzo-Ríos et al., 2020), Vicia fabae var. broad bean (Zhong et al. (2018), and Phaseolus vulgaris L. (Wani et al., 2017). The bulk density was similar to the previous report for lima beans (Gupta et al., 2018). Lima bean seed has a purple striped pattern (Figure 1). The colour of the mature seed and the young one is different, which is green. The increasing age of the seed changes the seed coat colour.

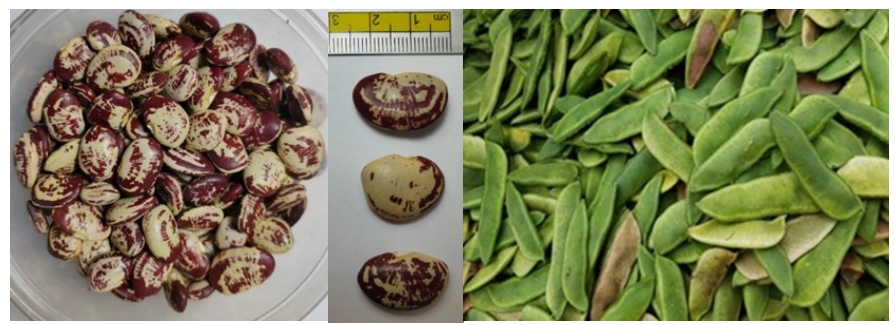

Figure 1. Indonesian dry seed and fresh pods of lima bean (Phaseolus lunatus L.)

\subsection{Chemical characteristics}

\subsubsection{Proximate composition}

Legumes are an excellent source of dietary proteins that play an important role in human nutrition by complementing other foods such as wheat and other cereals. Protein content generally falls between $15-30 \%$ (Hall et al., 2017). Lima beans are characterized as food sources with relatively high carbohydrates, rich in proteins but low in fat (Chel-Guerrero et al., 2012). The proximate composition of dry lima bean is shown in Table 2. Dry lima bean seed had a protein content of
$15.93 \pm 0.55 \%$ that was lower than that reported by Jayalaxmi et al. (2016) of 24.6\%, Drago et al. (2016) of $24.6 \%$, and Ibeabuchi (2019) of $16.81 \%$. The proteins in seeds of different lima beans showed significant variability that depends on their origins. Ash content represents the mineral content of the seeds. Lima bean contains $3.67 \pm 0.47 \%$ ash that was slightly higher than fava bean (3.40\%) (Millar et al., 2019), and the ash content of beans was in the range of 2-5\% (Hall et al., 2017). In this study, lima bean contained a very low fat $(1.15 \pm 0.04 \%$.). Lima bean contained carbohydrates of $62.8 \%$, protein of $20.62 \%$, fat of $0.93 \%$, and ash of $3.55 \%$ (USDA, 2018). However, the nutritional composition differs within a species, with variation attributable to genetic (G) and environmental components (E), as well as their interaction (GxE) (Halimi et al., 2019).

\subsubsection{Carbohydrate composition}

Carbohydrate plays an essential role in human nutrition, with starch representing a major source of calories, and dietary fibre contributing to gut health (Chibbar et al., 2010). The available carbohydrate of the dry lima bean seed is presented in Table 2. Starch was the major component of carbohydrates of lima bean with a concentration of $41.96 \pm 1.10 \%$, slightly higher than reported by Bello-Perez et al. (2007) with a 37-38\% concentration. This starch content was lower than Bambara groundnut (48.12\%) (Oyeleke et al., 2012) and in the range of mungbean starch content of 38.4-45.5\% (Skylas et al., 2017). In this study, amylopectin $(27.97 \pm 2.47 \%)$ was higher than amylose $(13.99 \pm 1.73 \%)$ in the lima bean's starch. Lima bean has higher amylopectin than amylose of $13.99 \%$, and this amylose content is lower than other legumes (Halimi et al., 2019).

Dietary fibre has an essential role in intestinal health and prevention of some diseases (Philips, 2013), has slow-release carbohydrates during digestion that are valuable in some disease management (Hayat et al., 2013). Lima bean is a source of dietary fibre comprised of soluble (SDF) and insoluble (IDF) fractions. The concentrations of total (TDF), soluble (SDF), and insoluble dietary fibre (IDF) reported for lima beans were $27.87 \pm 0.37 \%, 2.40 \%, 25.47 \%$, respectively, where insoluble fibre was the main fraction. These findings were different to $P$. vulgaris $(27.24 \%, 5.78 \%, 21.46 \%$,

Table 1. Physical characteristics of dry lima bean seed

\begin{tabular}{cccc}
\hline Physical characteristics & Value & Physical characteristics & Value \\
\hline Thickness $(\mathrm{cm})$ & $0.72 \pm 0.05$ & Yield of decorated seed $(\%)$ & $81.14 \pm 0.90$ \\
Width $(\mathrm{cm})$ & $1.50 \pm 0.08$ & Colour & \\
Length $(\mathrm{cm})$ & $2.32 \pm 0.08$ & L (lightness) & $73.70 \pm 0.98$ \\
Volume $/ 10$ seeds $(\mathrm{mL})$ & $9.67 \pm 0.29$ & + a (redness) & $16.70 \pm 0.10$ \\
Weight $/ 100$ seeds $(\mathrm{g})$ & $146.40 \pm 1.06$ & $+\mathrm{b}$ (yellowness) & $7.33 \pm 0.21$ \\
Bulk density $(\mathrm{g} / \mathrm{mL})$ & $1.51 \pm 0.37$ & & \\
\hline
\end{tabular}


Table 2. Chemical composition (in dry basis) and protein fractions of lima bean seed

\begin{tabular}{|c|c|c|c|}
\hline Component & Value & Component & Value \\
\hline Proximate (\%) & & Minerals (mg/100 g) & \\
\hline - Moisture & $11.78 \pm 0.85$ & - Calcium & $11.04 \pm 0.16$ \\
\hline - Protein & $15.93 \pm 0.55$ & - Iron & $10.19 \pm 0.02$ \\
\hline - Fat & $1.15 \pm 0.04$ & - Potassium & $38.21 \pm 0.01$ \\
\hline - Ash & $3.67 \pm 0.47$ & - Magnesium & $183.93 \pm 0.12$ \\
\hline - Carbohydrate & $68.89 \pm 1.55$ & - Phosphorus & $74.95 \pm 0.42$ \\
\hline Carbohydrate $(\%)$ & & Anti-nutrition & \\
\hline - Starch & $41.96 \pm 1.10$ & - Total phenolic compounds (mg/g) & $1.29 \pm 0.02$ \\
\hline - Amylose & $13.99 \pm 1.73$ & - Phytic acid (mg/g) & $11.57 \pm 0.03$ \\
\hline - Amylopectin & $27.97 \pm 2.47$ & - Saponins (mg/g) & $16.84 \pm 0.42$ \\
\hline - Total dietary fiber & $27.87 \pm 0.37$ & - Trypsin inhibitors (TIU/g) & $36.07 \pm 0.11$ \\
\hline - Soluble dietary fiber & $2.40 \pm 0.07$ & - Oligosaccharides (\%) & \\
\hline - Insoluble dietary fiber & $25.47 \pm 0.32$ & - $\quad$ Raffinose & $1.22 \pm 0.08$ \\
\hline - Oligosaccharides & $5.93 \pm 0.29$ & - Stachyose & $4.61 \pm 0.21$ \\
\hline Protein profile $(\%)$ & & Cyanide $(\mathrm{HCN})(\mathrm{mg} / \mathrm{kg})$ & $30.99 \pm 0.29$ \\
\hline - Albumin & $18.47 \pm 0.62$ & & \\
\hline - Globulin & $56.20 \pm 2.00$ & & \\
\hline - Prolamin & $3.14 \pm 0.20$ & & \\
\hline - Glutelin & $22.69 \pm 1.60$ & & \\
\hline
\end{tabular}

respectively) but similar to lentils of $26.86 \%$, $2.40 \pm 0.07 \%, 24.46 \pm 0.32 \%$, respectively (Duenas et al. 2016). Generally, pulses have higher IDF than SDF, with IDF ranging from 10 to $28 \%$, and SDF was lower than 10\% (Mudryj et al., 2014).

\subsubsection{Minerals}

Dry lima bean seed contains an appreciable amount of minerals represented by the ash of $3.30 \%$. Magnesium $(184 \mathrm{mg} / 100 \mathrm{~g})$, phosphorus $(75 \mathrm{mg} / 100 \mathrm{~g})$, potassium $(38 \mathrm{mg} / 100 \mathrm{~g})$, calcium $(11 \mathrm{mg} / 100 \mathrm{~g})$, and iron (10 $\mathrm{mg} / 100 \mathrm{~g}$ ) were found in dry lima bean seed (Table 1). Jayalaxmi et al. (2016) reported that lima beans contained minerals such as potassium, calcium, phosphorus, magnesium, sodium, iron, copper, and zinc. In comparison, mungbean had minerals which comprise magnesium (166 mg/100 g), potassium (363 mg/100 g), calcium $(1.2 \mathrm{mg} / 100 \mathrm{~g})$, and iron $(3.4 \mathrm{mg} / 100 \mathrm{~g})$ (Kumar and Pandey, 2020). Legumes are generally high in potassium, magnesium, iron, manganese, and other minerals of interest for the pulse family, such as calcium. The pulses' mineral composition varies and is affected by many factors, including genotype or cultivar and growing environment (Hall et al., 2017).

\subsubsection{Anti-nutrition and $\mathrm{HCN}$}

Although lima bean has good nutrition, it also contains anti-nutrients that can affect the bioavailability and digestibility of nutritional components (Boukid et al., 2016) and toxicant cyanide. The anti-nutrition of dry lima bean seeds is presented in Table 1 . Dry lima bean seed contains phytic acid of $11.57 \pm 0.03 \mathrm{mg} / \mathrm{g}$, which was higher than that reported by Bolade et al. (2017) of 8.86 $\mathrm{mg} / \mathrm{g}$. A wide range of variation in phytic acid concentration has been reported by Shi et al. (2018) for common beans of 15.64 to $18.32 \mathrm{mg} / \mathrm{g}$, pea of 9.93 to $12.27 \mathrm{mg} / \mathrm{g}$, and soybean of $22.91 \mathrm{mg} / \mathrm{g}$. Phytic acid is an important storage form of phosphorus in a plant and an abundant plant phosphorus constituent of the edible legumes, cereals, oilseeds, and nuts (Nissar et al., 2017). Phytic acid can form complexes with numerous divalent and trivalent ions such as phosphorus, zinc, calcium, and magnesium, thus reducing mineral bioavailability and nutrient deficiency (Campos-Vega et al., 2010).

Total phenolic compounds (TPC) in dry lima bean seed were $1.29 \pm 0.02 \mathrm{mg} / \mathrm{g}$. As a comparison TPC for pea (Pisum sativum) was 1.16 to $1.38 \mathrm{mg} / \mathrm{g}$, bean (Phaseolus vulgaris) was 1.59 to $4.33 \mathrm{mg} / \mathrm{g}$, and chickpea (Cicer arietinum) was 1.57 to $2.87 \mathrm{mg} / \mathrm{g}$ (Padhi et al., 2016). The phenolic composition is affected by genetic factors, climatic conditions, and variation in seed coat color. Phenolic compounds act as radical scavengers, reducing agents, and chelators of metal ions (Zhao et al., 2014).

Dry lima bean seed contained saponin of $16.84 \pm 0.42$ $\mathrm{mg} / \mathrm{g}$, which was higher than kidney bean of 9.40 to $11.80 \mathrm{mg} / \mathrm{g}$ (Shimelis and Rakshit, 2007), and 4 times greater than mungbean $(4.31 \mathrm{mg} / \mathrm{g})$, and was approximate to soybean of $18.56 \mathrm{mg} / \mathrm{g}$ (Lee et al., 2011). Saponins are sterol or triterpene glycosides and in plants are usually found as a non-polar aglycone moiety (or sapogenin) bound to sugar molecules. The amphiphilic nature of saponins makes them strong surface-active compounds. However, saponins have a bitter taste but are able to form stable foams in aqueous solutions. Saponins are widely distributed in plants, and the primary sources of saponins are legumes (Lee et al., 2011). These compounds are considered as an 
antinutritional factor, but recent studies show that saponin has blood cholesterol-lowering properties (Kumar and Pandey, 2020).

Trypsin inhibitors are a group of proteins that can reduce the digestive enzyme biological activity, trypsin and chymotrypsin. Trypsin is a proteolytic enzyme that is important for the digestion of proteins in living organisms (Vagadia et al., 2017). In this study, trypsin inhibitory activity of lima bean was $36.07 \pm 0.11 \mathrm{TIU} / \mathrm{g}$, which was higher than that reported by Bolade et al. (2018) of $29.3 \mathrm{TIU} / \mathrm{g}$ in the same legume and also higher than cowpea of $26.48 \mathrm{TIU} / \mathrm{g}$ (Kalpanadevi and Mohan, 2013). The level of trypsin inhibitor activity in legume seeds might be reduced by several small-scale processing methods, including water soaking, boiling, roasting, microwave cooking, autoclaving, fermentation, and micronization (Khattab and Arntfield, 2009).

Raffinose and stachyose were oligosaccharides in lima beans with $1.22 \pm 0.08 \%$ and $4.61 \pm 0.21 \%$, respectively. Stachyose and raffinose are also present in soybean at $0.9 \%$ and $4.1 \%$, respectively (Kumar and Pandey, 2020). There are limited data reporting oligosaccharide concentrations in lima bean seeds from other origins. Raffinose and stachyose are responsible for flatulence. However, more recent studies showed that they have prebiotic properties (Felker et al., 2018).

The HCN content in dry lima bean seed was $30.99 \pm 0.29 \mathrm{mg} / \mathrm{kg}$, and this concentration was lower than the report of Bolade et al. (2017) of $46.1 \mathrm{mg} / \mathrm{kg}$. Cyanogenic glucosides in lima beans are converted into $\mathrm{HCN}$ when the tissue is disrupted, and the release endogenous enzyme $b$ glucosidase and linamarase hydrolyse and liberate $\mathrm{HCN}$, a sugar, and a keto compound. Hydrolysis occurs rapidly when immersed seeds are cooked in water, and most of the HCN then evaporates. The processing methods (roasting, soaking, boiling, germination, cooking, and fermentation) are effective in reducing cyanide content in the raw lima bean seeds (Lim, 2012; Gänzle, 2020)

\subsection{Protein characteristics}

\subsubsection{Protein profile based on solubility}

The protein profile of dry lima bean seed based on solubility is shown in Table 1 . The predominant protein fraction was a salt-soluble fraction (globulins) of $56.20 \pm 2.00 \%$, followed by an alkali-soluble fraction (glutelins) of $22.69 \pm 1.60 \%$, and a water-soluble fraction (albumins) of $18.47 \pm 0.62 \%$. Prolamin was a minor alcohol-soluble fraction in the lima bean of $3.14 \pm 0.20 \%$ of the total seed proteins. This result was similar to the hyacinth with globulin of $55 \%$, glutelin of $27 \%$, and albumin of $18 \%$ (Subagio, 2006). In most pulses, globulin and albumin are the major seed storage proteins, such as in cowpea with globulin of $45 \%$ to $50.3 \%$, albumin of $31.2 \%$ to $35.5 \%$, respectively. Glutelin is the third most abundant protein, comprised of $15.1 \%$ to $20.5 \%$, while prolamin is a minor fraction that comprises 0.5 to $1.3 \%$ in seed (Alghamdi et al., 2019). The legumes protein profile is affected by genotypes, the cultivars, and the growing environment (Vasconcelos et al., 2010).

Characterization of the individual protein fractions of seed proteins is important as the basis for the legume protein utilization in food processing (Gupta et al., 2014). The electrophoretic pattern of the seed protein of the lima bean and its protein fractions are shown in Figure 2. The proteins of lima beans had a wide range of molecular weights between 10-141 $\mathrm{kDa}$ with 12 polypeptides. The molecular weight of these polypeptides are $10,12,14,20,22,27,35,48,70,85$, 116 , and $141 \mathrm{kDa}$, and five bands were the most highly intense bands with molecular weights of $14,20,35,48$, and $70 \mathrm{kDa}$. This electrophoretic protein pattern was similar to that found in cowpea. Gupta et al. (2014) reported that cowpea had 12-14 polypeptides with molecular weights of $10 ; 14.13 ; 17.78 ; 19.95 ; 22.39$; $28.18 ; 35.48 ; 44.67 ; 56.23 ; 97.72 ; 100 ; 104.7 ; 112.2$ and $141.3 \mathrm{kDa}$. Sparvoli et al. (1996) reported that the protein of lima bean had polypeptides with molecular weights of one band $(70 \mathrm{kDa})$, doublet $(54-58 \mathrm{kDa})$, triplet $(32,35$, and $38.5 \mathrm{kDa})$. The doublet $(21-25 \mathrm{kDa})$ polypeptides were identified as phaseolin. Soetan and Animasaun (2019) reported that the molecular weight of protein in lima bean was distributed in the range of 11 to $135 \mathrm{kDa}$. García-Mora et al. (2015) reported a protein profile from Phaseolus vulgaris. var. pinto, with bands between 10 to $97 \mathrm{kDa}$. Bands with molecular weights of 25,45 , and $50 \mathrm{kDa}$ were identified as phaseolin.

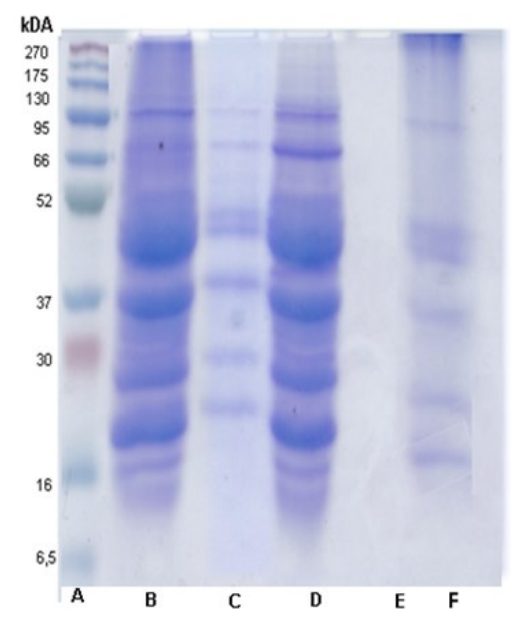

Figure 2. Protein fractions of dry lima bean seed in SDSpolyacrylamide gel electrophoresis. Line A: protein marker, B: total protein, C: albumin, D: Globulin, E: Prolamin, F: Glutelin 
Globulin fraction of lima bean had 12 bands with molecular weight ranging between 10 to $124 \mathrm{kDa}$. The molecular weights of the polypeptides were $10,13,15$, 22, 24, 27, 35, 48, 66, 90, 116, $124 \mathrm{kDa}$. Albumin had 18 to $116 \mathrm{kDa}$ molecular weights, while glutelin fraction had six bands with a molecular weight of 13 to $109 \mathrm{kDa}$. According to Alghamdi et al. (2019), molecular weights of cowpea protein varied between 10 to 250,15 to 110 , 15 to 150 , and 15 to $130 \mathrm{kDa}$ for all protein, albumin, globulin, and glutelin, respectively, with some variations in number, width, and intensity of bands. Prolamin of lima bean in this study did not have visible polypeptides, and this finding was in accordance with cowpea reported by Alghamdi et al. (2019). Legumes have low prolamin concentration, and prolamin is mainly found in cereals (Tchiagam et al., 2011).

\subsubsection{Amino acids composition}

The protein quality of foods is assessed based on quantifying essential amino acids compared to nutritional requirements (Vaz Patto et al., 2015). The composition of essential and non-essential amino acids of lima beans is presented in Table 3. Lima bean contained a significant amount of essential amino acids. Lysine, leucine, valine, and phenylalanine were the major essential amino acids, and lima bean was rich in lysine. On the contrary, lima beans lacked methionine and cysteine (sulfur-containing amino acids). Methionine and cysteine are limiting amino acids of pulse proteins. Generally, the legume is an excellent ingredient combined in cereal-based flour blends to obtain a balanced and complete amino acid profile (Millar et al., 2019).

In this study, glutamic acid and aspartic acid were the two most abundant non-essential amino acids. Both were predominant non-essential amino acids legumes (Hall et al., 2107; Teka et al., 2020) and Bambara groundnut (Halimi et al., 2019). Globulins contained higher concentrations of glutamine, aspartic acid, and arginine than albumins and low concentrations of sulfurcontaining amino acids (methionine, cysteine) and tryptophan (Dahl, 2012). Cysteine, methionine, and lysine contents were higher in the albumin fraction than beans' globulins (Semba et al., 2016).

\section{Conclusion}

Dry lima bean seed was a good nutrition source with a moderate concentration of protein, low in fat, and relatively high carbohydrates, which starch as a major source of carbohydrates and dietary fibre was in an appreciable amount. The globulins were the major seed protein, followed by glutelin and albumin, while prolamin was found in very low quantity. Lima bean seed was rich in essential amino acids. Like other legumes, it lacked methionine and cysteine. Dry lima bean was rich in minerals including magnesium, potassium, calcium, phosphorus, and iron, with the most abundant mineral, was magnesium. Some antinutritional compounds were found that included trypsin inhibitors, phytic acid, saponin, phenolic compounds, oligosaccharides, and a toxicant HCN.

\section{Conflict of interest}

The authors declare no conflict of interest.

\section{Acknowledgment}

The authors would like to thank the Ministry of Education and Culture, The Republic of Indonesia, for funding this research through Penelitian Disertasi Doktor in the Year 2020 with Contract No. 127/SP2H/LT/ DRPM/2020.

\section{References}

Agarwal, A. (2017). Proteins in pulses. Journal of Nutritional Disorders Therapy, 7(1), 2161-0509. https://doi.org/10.4172/2161-0509.1000e129

Alghamdi, S.S., Khan, M.A., Migdadi, H.M., El-Harty, E.H., Afzal, M. and Farooq, M. (2019). Biochemical and molecular characterization of cowpea landraces using seed storage proteins and SRAP marker patterns. Saudi Journal of Biological Science, 26(1),

Table 3. Amino acids of dry lima bean compared to the FAO amino acids standard

\begin{tabular}{cccccc}
\hline Amino Acids (mg/g) & Lima Bean & *FAO Standard & Amino Acids $(\mathrm{mg} / \mathrm{g})$ & Lima Bean & *FAO Standard \\
\hline Isoleucine & 908 & 1100 & Valine & 983 & 1260 \\
Phenylalanine & 1283 & 1200 & Tyrosine & 555 & 740 \\
Glutamic acid & 2138 & 2960 & Methionine & 78 & 264 \\
Leucine & 1567 & 1800 & Cystine & 19 & 231 \\
Aspartic acid & 1726 & 2700 & Histidine & 624 & 639 \\
Lysine & 1014 & 1400 & Threonine & 1027 & 903 \\
Glycine & 885 & 883 & Proline & 736 & 950 \\
Arginine & 1355 & 1280 & Serine & 1424 & 1390 \\
Alanine & 755 & 1070 & & & \\
\hline
\end{tabular}

*Source: Food And Agriculture Organization of the United Nations (2016) 
74-82. https://doi.org/10.1016/j.sjbs.2018.09.004

AOAC. (2005). Official Method of Analytical of The Association of Official Analytical of Chemist: Association of Official Analytical Chemist (AOAC). Washington DC, USA: AOAC.

Aremu, M.O., Ibrahim, H. and Ekanem, B.E. (2016). Effect of processing on in-vitro protein digestibility and antinutritional properties of three underutilized legumes grown in Nigerian. British Biotechnology Journal, 14(1), 22581. https://doi.org/10.9734/ $\mathrm{BBJ} / 2016 / 22581$

Bello-Pérez, L.A., Sáyago-Ayerdi, S.G., ChávezMurillo, C.E., Agama-Acevedo, E. and Tovar J. (2007). Proximal composition and in vitro digestibility of starch in lima bean (Phaseolus lunatus) varieties. Journal of Science Food and Agriculture, 87(14), 2570-2575. https:// doi.org/10.1002/jsfa.3005

Bolade, M.K., Agarry, I.E. and Bolade, O.O. (2017). Impact of trona-aided boiling on the phytochemical constituents and beneficial micronutrients of lima bean (Phaseolus lunatus L.). African Journal of Biotechnology, 16(43), 2062-2071. https:// doi.org/10.5897/AJB2017.16191

Boukid, F., Zannini, E., Carini, E. and Vittadini, E. (2019). Pulses for bread fortification: A necessity or a choice? Trends in Food Science and Technology, 88, 416-428. https://doi.org/10.1016/ j.tifs.2019.04.007

Campos-Vega, R., Loarca-Piña, G. and Oomah, B.D. (2010). Minor components of pulses and their potential impact on human health. Food Research International, 43(2), 461-482. https:// doi.org/10.1016/j.foodres.2009.09.004

Chel-Guerrero, L., Domínguez-Magaña, M., MartínezAyala, A., Dávila-Ortiz, G. and Betancur-Ancona, D. (2012). Lima bean (Phaseolus lunatus) protein hydrolysates with ACE-I inhibitory activity. Food Nutrition and Sciences, 3(4), 511-521. https:// doi.org/10.4236/fns.2012.34072

Chibbar, R.N., Ambigaipalan, P. and Hoover, R. (2010). Review: molecular diversity in pulse seed starch and complex carbohydrates and its role in human nutrition and health. Cereal Chemistry, 87(4), 342352. https://doi.org/10.1094/CCHEM-87-4-0342

Corzo-Ríos, L.J., Sánchez-Chino, X.M., CardadorMartínez, A., Martínez-Herrera, J. and JiménezMartínez, C. (2020). Effect of cooking on nutritional and non-nutritional compounds in two species of Phaseolus ( $P$. vulgaris and $P$. coccineus) cultivated in Mexico. International Journal of Gastronomy and Food Science, 20, 100206. https://doi.org/10.1016/

\section{j.ijgfs.2020.100206}

Dahl, W.J., Foster, L.M. and Tyler, R.T. (2012). Review of the health benefits of peas (Pisum sativum L.). British Journal of Nutrition, 108(Suppl. 1), S3-S10. https://doi.org/10.1017/S0007114512000852

Diniyah, N., Alam, M.B. and Lee, S.H. (2020). Antioxidant potential of non-oil seed legumes of Indonesian's ethnobotanical extracts. Arabian Journal of Chemistry, 13(5), 5208-5217. https:// doi.org/10.1016/j.arabjc.2020.02.019

Drago, S.R., Franco-Miranda, H., Cian, R.E., BetancurAncona, D. and Chel-Guerrero, L. (2016). Bioactive properties of Phaseolus lunatus (lima bean) and Vigna unguiculata (cowpea) hydrolyzates incorporated into pasta. Residual activity after pasta cooking. Plant Foods for Human Nutrition, 71(3), 339-345. https://doi.org/10.1007/s1 1130-016-0565-2

Duenas, M., Sarmento, T., Aguilera, Y., Benitez, V., Mollá, E., Esteban, R.M. and Martín-Cabrejas, M.A. (2016). Impact of cooking and germination on phenolic composition and dietary fibre fractions in dark beans (Phaseolus vulgaris L.) and lentils (Lens culinaris L.). LWT-Food Science and Technology, 66, 72-78. https://doi.org/10.1016/j.lwt.2015.10.025

e Lacerda, R.R., do Nascimento, E.S., de Lacerda, J.T.J.G., Pinto, S.L. and Rizzi C. (2017). Lectin from seeds of a Brazilian lima bean variety (Phaseolus lunatus L. var. cascavel) presents antioxidant, antitumor, and gastroprotective activities. International Journal of Biological Macromolecules, 95, 1072-1081. https://doi.org/10.1016/ j.ijbiomac.2016.10.097

Food and Agriculture Organization of the United Nations. (2016). Pulses Nutrition: Seeds for Sustainable Future, p. 1-196. Rome: FAO.

Felker, F.C., Kenar, J.A., Byars, J.A., Singh, M., and Liu, S.X. (2018). Comparison of properties of raw pulse flours with those of jet-cooked, drum-dried flours. LWT-Food Science and Technology, 96, 648656. https://doi.org/10.1016/j.lwt.2018.06.022

García-Mora, P., Frias, J., Peñas, E., Zieliński, H., Giménez-Bastida, J.A. Wiczkowski, W., Zielińska, D. and Martínez-Villaluenga, C. (2015). Simultaneous release of peptides and phenolics with antioxidant, ACE-inhibitory, and anti-inflammatory activities from pinto bean (Phaseolus vulgaris L. var. pinto) proteins by subtilisins. Journal of Functional Foods, 18(Part A), 319-332. https://doi.org/10.1016/ j.jff.2015.07.010

Gupta, P., Singh, R., Malhotra, S., Boor, K.S. and Singal, H.R. (2014). Cowpea seed proteins: heterogeneity in total proteins and protein fractions. 
Legume Research - An International Journal, 37(1), 62-67. https://doi.org/10.5958/j.0976-0571.37.1.009

Gupta, S., Chhabra, G.S., Liu, C., Bakshi, J.S. and Sathe, S.K. (2018). Functional properties of selected dry bean seeds and flours. Journal of Food Science, 83 (8), 2052-2061. https://doi.org/10.1111/17503841.14213

Hall, C., Hillen, C. and Robinson, J.G. (2017). Composition, nutritional value, and health benefits of pulses. Cereal Chemistry, 94(1), 11-31. https:// doi.org/10.1094/CCHEM-03-16-0069-FI

Halimi, R.A., Barkla, B.J., Mayes, S. and King, G.J. (2019). The potential of the underutilized pulse Bambara groundnut (Vigna subterranea (L.) Verdc.) for nutritional food security. Journal of Food Composition and Analysis, 77, 47-59. https:// doi.org/10.1016/j.jfca.2018.12.008

Hayat, I., Ahmad, A., Masud, T., Ahmed, A. and Bashir, S. (2014). Nutritional and health perspectives of beans (Phaseolus vulgaris L.): an overview. Critical Review in Food Science and Nutrition, 54(5), 580592. https://doi.org/10.1080/10408398.2011.596639

Ibeabuchi, J.C., Okafor, D.C., Ahaotu, N.N., Eluchie, C.N., Agunwah, I.M., Chukwu, M.N. and Amandikwa, C. (2019). Effect of dehulling on proximate composition and functional properties of lima bean (Phaseolus lunatus) grown in Enugu State. Journal of Food Research, 8(2), 116-121. https:// doi.org/10.5539/jfr.v8n2p116

Jayalaxmi, B., Vijayalakshmi, D., Usha, R., Revanna, M.L., Chandru, R. and Gowa, P.H.R. (2016). Effect of different processing methods on proximate, mineral, and antinutrient content of lima bean (Phaseolus lunatus) seeds. Legume Research - An International Journal, 39(4), 543-549. https:// doi.org/10.18805/lr.v0iOF.7108

Kakade, M.L., Rackis, J.J., McGhee, J.E. and Pusky, G. (1974). Determination of trypsin inhibitor activity of soy products: a collaborative analysis of an improved procedure. Cereal Chemistry, 51(3), 376-382.

Kalpanadevi, V. and Mohan, V.R. (2013). Effect of processing on antinutrients and in vitro protein digestibility of the underutilized legume, Vigna unguiculata (L.) Walp subsp. unguiculata. LWTFood Science and Technology, 51(2), 455-461. https://doi.org/10.1016/j.lwt.2012.09.030

Khattab, R.Y. and Arntfield, S.D. (2009). Nutritional quality of legume seeds as affected by some physical treatments 2. Antinutritional factors. LWT-Food Science and Technology, 42(6), 1113-1118. https:// doi.org/10.1016/j.lwt.2009.02.004

Kumar, S. and Pandey, G. (2020). Biofortification of pulses and legumes to enhance nutrition. Heliyon, 6 (3), e03682. https://doi.org/10.1016/ j.heliyon.2020.e03682

Lai, L.R., Hsieh, S.C., Huang, H.Y. and Chou, C.C. (2013). Effect of lactic fermentation on the total phenolic, saponin, and phytic acid contents as well as anti-colon cancer cell proliferation activity of soymilk. Journal Bioscience and Bioengineering, 115(5), 552-556. https://doi.org/10.1016/ j.jbiosc.2012.11.022

Lee, J.H., Jeon, J.K., Kim, S.G., Kim, S.H., Chun, T. and Imm, J.Y. (2011). Comparative analyses of total phenols, flavonoids, saponins, and antioxidant activity in yellow soybeans and mung beans. International Journal of Food Science and Technology, 46(12), 2513-2519. https:// doi.org/10.1111/j.1365-2621.2011.02775.x

Lim, T.K. (2012). Edible Medicinal and Non-Medicinal Plants. Vol. 2. Fruits. Dordrecht, The Netherlands: Springer. https://doi.org/10.1007/978-94-007-4053-2

Millar, K.A., Gallagher, E., Burke, R., McCarthy, S. and Barry-Ryan, C. (2019). Proximate composition and antinutritional factors of fava-bean (Vicia faba), green-pea, and yellow-pea (Pisum sativum) flour. Journal of Food Composition and Analysis, 82, 103233. https://doi.org/10.1016/j.jfca.2019.103233

Mudryj, A.N., Yu, N. and Aukema, H.M. (2014). Nutritional and health benefits of pulses. Applied Physiology, Nutrition, and Metabolism, 39(11), 1197 -1204. https://doi.org/10.1139/apnm-2013-0557

Nissar, J., Ahad, T., Naik, H.R. and Hussain, S.Z. (2017). A review of phytic acid: As antinutrient or nutraceutical. Journal of Pharmacognosy and Phytochemistry, 6(6), 1554-1560.

Oyeleke, G.O., Afolabi, O. and Isola, A.D. (2012). Some quality characteristics and carbohydrate fractions of Bambara groundnut (Vigna subterranea L.) seed flour. IOSR Journal of Applied Chemistry, 2(4), 1619. https://doi.org/10.9790/5736-0241619

Padhi, E.M., Liu, R., Hernandez, M., Tsao, R. and Ramdath, D.D. (2017). Total polyphenol content, carotenoid, tocopherol, and fatty acid composition of commonly consumed Canadian pulses and their contribution to antioxidant activity. Journal of Functional Foods, 38(Part B), 602-611. https:// doi.org/10.1016/j.jff.2016.11.006

Philips, G.O. (2013). Dietary fiber: a chemical category or a health ingredient? Bioactive Carbohydrates and Dietary Fibre, 1(1), 3-9. https://doi.org/10.1016/ j.bcdf.2012.12.001

Sandoval-Peraza, M., Peraza-Mercado, G., BetancurAncona, D., Castellanos-Ruelas, A. and Chel- 
Guerrero, L. (2020). Lima Bean. In Manickavasagan, A. and Thirunathan (Eds). Pulses: Processing and Product Development. Switzerland: Springer. https:// doi.org/10.1007/978-3-030-41376-7 9

Semba, R.D., Shardell, M., Ashour, F.A.S., Moaddel, R., Trehan, I., Maleta, K.M., Ortiz, M.I., Kraemer, K., Khadeer, M.A., Ferrucci, L. and Manaryet, M.J. (2016). Child stunting is associated with low circulating essential amino acids. Biomedicine, 6, 246-252. https://doi.org/10.1016/ j.ebiom.2016.02.030

Shi, L., Arntfield, S.D. and Nickerson, M. (2018). Changes in levels of phytic acid, lectins, and oxalates during soaking and cooking of Canadian pulses. Food Research International, 107, 660-668. https://doi.org/10.1016/j.foodres.2018.02.056

Shimelis, E.A. and Rakshit, S.K. (2007). Effect of processing on antinutrients and in vitro protein digestibility of kidney bean (Phaseolus vulgaris L.) varieties grown in East Africa. Food Chemistry, 103 (1), 161-172. https://doi.org/10.1016/ j.foodchem.2006.08.005

Soetan, K.O. and Animasaun, D.A. (2019). Characterization and profiling of seed storage proteins of some underutilized bean varieties using the SDS-PAGE. Journal of Animal and Plant Science, 29(6), 1622-1629.

Skylas, D.J., Blanchard, C.L. and Quail, K.J. (2017). Variation in the nutritional composition of Australian mungbean varieties. Journal of Agricultural Science, 9(5), 45-53. https:// doi.org/10.5539/jas.v9n5p45

Sparvoli, F., Daminati, M.G., Liu, L. and Bollini, R. (1996). In vivo endoproteolytically cleaved phaseolin is stable and accumulates in developing Phaseolus lunatus L. seeds. Biochimica et Biophysica Acta Protein Structure and Molecular Enzymology, 1292 (1), 15-22. https://doi.org/10.1016/0167-4838(95) 00176-X

Subagio, A. (2006). Characterization of hyacinth bean (Lablab purpureus (L.) sweet) seeds from Indonesia and their protein isolate. Food Chemistry, 95(1), 6570. https://doi.org/10.1016/j.foodchem.2004.12.042

Teka, T.A., Retta, N., Bultosa, G., Admassu, H. and Astatkie, T. (2020). Protein fractions, in vitro protein digestibility, and amino acid composition of select cowpea varieties grown in Ethiopia. Food Bioscience, 2020, 100634. https://doi.org/10.1016/ j.fbio.2020.100634

Tchiagam, L.B.N., Bell, J.M., Nassourou, A.M., Njintang, N.Y. and Youmbi, E. (2011). Genetic analysis of seed protein contents in cowpea (Vigna unguiculata. L. Walp.). African Journal of
Biotechnology, 10(16), 3077-3086. https:// doi.org/10.5897/AJB10.2469

USDA (U.S. Department of Agriculture Research Service). (2018). Lima beans, thin seeded (baby), mature seeds, raw. Retrieved on 11 November 2020 from https://fdc.nal.usda.gov.

Vagadia, B.H., Vanga, S.K. and Raghavan, V. (2017). Inactivation methods of soybean trypsin inhibitor-A review. Trends in Food Science and Technology, 64, 115-125. https://doi.org/10.1016/j.tifs.2017.02.003

Vasconcelos, I.M., Maia, F.M.M., Farias, D. and Campello, C.C. (2010). Protein fractions, amino acid composition, and antinutritional constituents of highyielding cowpea cultivars. Journal of Food Composition and Analysis, 23(1), 54-60. https:// doi.org/10.1016/j.jfca.2009.05.008

Vaz Patto, M.C., Amarowicz R., Aryee A.N.A., Boye J.I., Chung H.J., Martín-Cabrejas, M.A. and Domoney, C. (2015). Achievements and challenges in improving the nutritional quality of food legumes. Critical Review in Plant Sciences, 34(1-3), 105-143. https://doi.org/10.1080/07352689.2014.897907

Wang, Q., Ke, L., Yang, D., Bao, B. and Jiang, J. (2007). Change in oligosaccharides during the processing of soybean sheet. Asia Pacific Journal of Clinical Nutrition, 16(Suppl. 1), 89-94.

Wani, I.A., Sogi, D.S., Wani, A.A. and Gill, B.S. (2017). Physical and cooking characteristics of some Indian kidney bean (Phaseolus vulgaris L.) cultivars. Journal of the Saudi Society of Agricultural Sciences, 16(1), 7-15. https://doi.org/10.1016/ j.jssas.2014.12.002

Wati, R.K, Theppakorn, T., Benjakul, S. and Rawdkuen, S. (2009). Three-phase partitioning of trypsin inhibitor from legume seeds. Process Biochemistry, 44(12), 1307-1314. https://doi.org/10.1016/ j.procbio.2009.07.002

Zhong, L., Fang, Z., Wahlqvist, M.L., Wu, G., Hodgson, J.M. and Johnson, S.K. (2018). Seed coats of pulses as a food ingredient: Characterization, processing, and applications. Trends in Food Science and Technology, 80, 35-42. https://doi.org/10.1016/ j.tifs.2018.07.021

Zhao, Y., Du, S.K., Wang, H. and Cai, M. (2014). In vitro antioxidant activity of extracts from common legumes. Food Chemistry, 152, 462-466. https:// doi.org/10.1016/j.foodchem.2013.12.006 